\title{
KEBIJAKASANAAN DAN COMPLEX POLITICAL EMERGENCE: Mencermati Arah Konflik Jamaah Ahmadiyah Indonesia
}

\author{
Ihsan Rahmat* \\ E-mail: ihsanrahmat@iainbengkulu.ac.id
}

\begin{abstract}
Abstrak
Complex Political Emergence (CPE) menjadi paradigma yang mampu menjelaskan saat sebuah konflik tidak mampu dikelola dan diprediksi penyelesaiannya. Perang yang kemudian merambah pada isu kemanusiaan, ideologi, dan keterbatasan sumberdaya seringkali menjadi contoh mutlak. Tetapi tidak menutup kemungkinan bergeser ke konflik laten agama. Menimbang hal tersebut, studi ini kemudian berargumen bahwa masa konflik Ahmadiyah dengan 'muslim tertentu' di Indonesia kemungkinan mengarah pada CPE. Diskusi pada tulisan ini telah didukung oleh berbagai jurnal, pandangan tokoh, dan berita dari media online. Semua bahan dibaca secara interaktif, direduksi, kemudian intisari bacaan dikembangkan sesuai penalaran induktif. Studi ini memaparkan beberapa bukti kasus kekerasan, bahkan penghilangan nyawa di kalangan warga Ahmadiyah. Penyebabnya dalam CPE dikenal dengan predatory social formations atau penanaman pemikiran bahwa Ahmadiyah merusak akidah Islam dan diklaim sesat. Sehingga saat 'muslim tertentu' bertemu dengan pengikut Ahmadiyah, keinginan untuk mengadakan kontak sangat mungkin terjadi. Ini menjadi jawaban penting bahwa konfliknya mengarah pada CPE.
\end{abstract}

Kata Kunci : Konflik, Complex Political Emergence, Kebijakan Publik, Ahmadiyah

\section{Pendahuluan}

Konflik adalah perjuangan. Konflik menjadi salah satu alat untuk menunjukkan klaim dan sistem nilai yang dianut oleh satu atau beberapa individukelompok. Makna ini berujung pada praktik-praktik negatif. Konflik juga dapat dipandang dari sudut positif yakni sebagai bentuk interaksi sosial yang berkontribusi untuk memelihara atau merubah tatanan sosial. Meskipun sisi negatif dan positif dari konflik itu ada, permasalahannya tetaplah berhulu pada perjuangan dalam rangka menguasai keterbatasan sumber daya (alam dan manusia). Dalam konteks ini, kehadiran negara menjadi sebuah keharusan (final fix) sebagai pihak yang 'mensintesiskan' kebutuhan pihak yang berkonflik sembari menjaga keterbatasan sumber daya. Negara hadir sebagai aktor yang memiliki otoritas melalui tools yang bernama kebijakan.

Kebijaksanaan atau kebijakan publik yang dimaknai sebagai serangkaian aturan main yang idealnya berbicara tentang keteraturan, seringkali tidak menyelesaikan permasalahan. Justru dalam beberapa kasus konflik, kebijakan publik menjadi pemicunya. Dunn telah 
mengingatkan bahwa sangat sulit untuk sebuah kebijakan mengakomodir kehendak seluruh pihak. $^{1}$ Selalu ada kemungkinan kebijakan memuaskan beberapa golongan dan mengkerdilkan satu golongan atau sebaliknya. ${ }^{2}$ Pada tahap ini sebenarnya kita sudah dapat mempertanyakan kontradiksi ini.

Akan tetapi, dalam tulisan ini penulis tidak lagi mengkaji hal demikian. Tulisan ini akan mengkaji konflik-konflik yang pada satu sisi sudah memiliki kebijakan, pada sisi lain kebijakan yang dihasilkan tidak memberi penyelesaian yang berarti. Konflik yang dimaksud sering dinamakan complex political emergence (CPE), di mana jangka waktu awal terjadi dan sampai kapan konflik ini akan terjadi, tidak dikatahui. CPE adalah deskripsi konflik yang paling akut, menyinggung berbagai aspek seperi politik, sosio-kultur, menganggap kelompok lain sebagai predator dan antipati.

Tulisan ini akan mencoba menjawab permasalahan di atas, yakni bagaimana kebijakan publik sebagai sebuah tools negara, mampu mengelola konflik yang sudah berada pada taraf complex political emergence. Argumennya adalah konflik, apapun tingkatanya, merupakan sebuah keniscayaan dalam kebijakan publik. Prevalensi yang muncul akibat potensi alamiah ini diperparah oleh cara para pembuat kebijakan(policymaker)yang mengelola kebijakan publik cenderung ikut bermain (memiliki kepentingan lain) dalam penyelesaian konflik. Asumsinya adalah kebijakan publik akan menyelesaikan CPE apabila seluruh aktor yang terlibat mau bersama-sama mengurangi prinsip nilai, klaim, dan kepentingan untuk bersama fokus membangun keteraturan dan perdamaian. Selama ketiga hal pokok ini kurang mendapatkan perhatian dari tiap aktor, apapun jenis kebijakan publik yang dibuat tetap menjadi sebuah keniscayaan dalam konflik.

Indonesia sebagai negara yang mendapat perhatian dunia terkait kemampuan dalam mengelola keberagaman dinilai tidak mampu lepas dari konflik agama. Terhitung sudah banyak konflik yang berlatar agama muncul di Indonesia. Beberapa konflik yang terus mendapatkan perhatian hingga saat ini adalah konflik Ahmadiyah, Syiah, dan Poso. Sebagai studi kasus, tulisan ini mengangkat konflik agama yang ditimbulkan oleh Jamaah Ahmadiyah Indonesia (JAI) dengan umat Islam khususnya 'kelompok Islam tertentu'.

Selain membahas kebijakan dan CPE dalam tataran teoritis, tulisan ini juga mencoba mengelaborasi substansi empiris 


\section{Ihsan Rahmat \\ KEBIJAKASANAAN DAN CDMPLEX PDLITILAL EMERGENCE}

dengan mengambil studi kasus kebijakan terkait Jamaah Ahmadiyah Indonesia (JAI), sejak munculnya SKB 3 Menteri (Kemendagri, Kemenag, dan Jaksa Agung) hingga kasus-kasus kualitatif yang timbul di berbagai daerah seperti pembakaran Masjid Ahmadiyah di Bekasi. Melalui alur berpikir ini, kajian ini diharapkan memberikan penjelasan tentang peran kebijakan publik dalam paradigma CPE. Kemudian mampu mengembalikan kebijakan publik sebagai penyeimbang dalam kehidupan bernegara yang sekarang ini sudah terabaikan.

\section{A. Diagnosa Konflik Kebijakan}

Webster menjelaskan konflik dalam bahasa aslinya berarti suatu "perkelahian, peperangan, atau perjuangan" - yaitu berupa konfrontasi fisik antara satu pihak dengan pihak lain atau beberapa pihak dengan satu pihak (fleksibel). ${ }^{3}$ Untuk sekarang, arti kata konflik mengalami perkembangan dengan masuknya "ketidaksepakatan yang tajam atauoposisi atas berbagai kepentingan, ide, dan lainlain."4

Pengertian yang kedua ini, tidak mengharuskan adanya kontak fisik dengan pihak lain, jalur diplomasi menjadi salah satu cara penyelesaiannya. Kata kunci konflik berhulu pada disharmonisasi nilai dan kepentingan. ${ }^{5}$
Dengan kata lain, peradaban itu sendiri adalah sahabat konflik karena secara natural setiap aktor yang berada di dalamnya memiliki kepentingan dan nilai yang berbeda untuk diwujudkan secara maksimal. Jelas bahwa konflik tidak perlu dan tidak dapat dihindari tetapi harus dikelola secara baik. Persoalannya kemudian adalah siapa yang berwenang untuk mengelola konflik?

Cliffe dan Luckham menjelaskan bawah negara memiliki kewenangan primer dalam menyelesaikan berbagai konflik. ${ }^{6}$ Sesungguhnya sejak negara ada, rakyat telah memberikan kewenangan hidup mereka untuk diatur. Ada kontrak sosial yang tidak tertulis bahwa negara harus mengurus rakyat dan rakyat wajib taat kepada hukum negara. Mengingat keterbatasan sumber daya yang dimiliki, negara melalui otoritasnya harus menjadi penyeimbang (balancing) bahkan menyelesaikan konflik berdasarkan pada asas keadilan (fairness).

Dalam konflik, posisi negara harus kuat. Kegagalan negara dalam mengeola isu konflik akan menimbulkan distrust bahkan pengalaman dibeberapa negara berakhir pada perang dan kematian. Otoritas negara hadir dalam berbagai kebijakan publik. Kebijakan inilah yang nantinya akan memberikan aturan main di lapangan (level playing field). Pihak-pihak 
yang berkonflik memiliki kewajiban untuk mentaati, tanpa itu kebijakan hanyalah sukumpulan ide brilian yang tidak bernilai guna dan hasil.

Bagaimana jika sebaliknya yakni kebijakan yang menyebabkan konflik? Karena ketidakmampuan otoritas dalam mengelola konflik atau pada kasus lain kebijakan yang dibuat otoritas menimbulkan pertentangan nilai dan kepentingandalam masyarakat.7 Banyak contoh kasus Indonesia yang kebijakannya menyebabkan permasalahan di masyarakat. RUU Keistimewaan Yogyakarta, Peraturan daerah tentang miras di Maluku Utara, UU terkait perluasan hutan di Indonesia, menjadi segelintri kebijakan yang mendapat respon penolakan.

Kebanyakan kebijakan yang menimbulkan konflik ini disebabkan oleh: 1) kepentingan beberapa pihak untuk melancarkan urusan; 2) kurangnya pengetahuan tentang kebijakan; 3) ketidakpahaman policymaker tentang kondisi lapangan; dan 4) aspek sosial dan budaya tiap daerah cenderung berbeda tetapi policymaker kurang menganalisa. Karena itu, dalam kebijakan dikenal istilah evidence based yakni segala kebijakan harus berdasarkan data primer lapangan. Untuk data skunder, dapat digunakan dengan melihat kredibilitas instansi yang 64 mengeluarkan data. Data dalam kebijakan publik bukan hanya yang bersifat kuantitatif, kualitatif juga menjadi perhatian utama. Kebijakan yang sering menuai kontra sering kali hanya menggunakan data kuantitatif dan melupakan data kualitatif.

Ekspektasi yang begitu tinggi terhadap pemerintah untuk menjawab persoalan masyarakat melalui produk kebijakan publik sangatlah beralasan. Sandaran filosofisnya yang paling dasar adalah kontral sosial alamiah yang disebutkan sebelumnya. Merujuk pada kontrak tersebut, menyelesaikan berbagai persoalan publik bukanlah pilihan bagi pemerintah namun sebuah kaharusan. Secara normative pula pemrintah tidak bisa memilih hanya menyelesaikan persoalan tertentu dan mengabaikan yang lainnya. Walau belakangan, pemerintah “dibenarkan" untuk memilih persoalan mana yang harus diselesaikan dan mana yang bisa ditunda, atau bahkan diabaikan, dengan dalihketerbatasan kapasitas atau sumber daya yang dimiliki.

Tingginya ekspektasi masyarakat tersebut dikarenakan semakin kompleksnya masalah-masalah publik yang dihadapi secara kolektif oleh warga negara di tengah meningkatkanya standar normatif yang ditentukan masyarakat untuk menilai dan menuntut pemerintah. 
Belumlagi, seperti yang telah dijelaskan di atas, terkait konflik yang telah memakan waktu yang sangat lama (long duration) atau yang kita sebut dengan CPE. Diagnosa konflik kebijakan lain yang muncul adalah terkait isu desentralisasi wilayah. Alih-alih bermaksud mendistribusikan kewenangan pusat ke daerah, ternyata setiap daerah memberikan respon yang beragam. Ada daerah kabupaten/kota yang siap dengan mekanisme otonomi daerah dikarenakan adanya pemasukan APBD dari faktor alam, kesiapan dari sektor sumber daya manusia, sistem yang mumpuni, dan teknologi yang baik. Tetapi juga ada daerah yang belum siap menerima beban pengelolaan keuangan daerah secara mandiri, sehingga menimbulkan konflik penguasaan sumber daya.

Dengan menghadirkan paradoks semacam ini, sama sekali tidak berpotensi menghilangkan kebijakan publik secara total. Sebaliknya, paradox tersebut menyediakan basis pembelajaran yang sangat baik untuk memperbaiki kebijakan publik di masa-masa yang akan datang agar kebijakan mampu menjalankan fungsi klasiknya secara lebih optimal, yakni menjadi instrument otoritatif yang mampu mengalokasikan keterbatasan sumber daya dan nilai secara baik sehingga sekaligus berfungsi sebagai media pengelola konflik. Dengan kata lain, kebijakan yang baik adalah kebijakan yang mampu meniadakan dan mengadakan konflik.

\section{B. Memahami Complex Political \\ Emergence}

Ketika abad ke-20 memasuki masa senja, ada perubahan yang fundamental pada model konflik kekerasan berskala besar. Goodhand dan Hulme terkadang menggunakan istilah contemporary conflict untuk menjelaskan suatu keadaan dimana era perang besar berubah ke era yang disebut CPE. ${ }^{8}$ CPE bisa dikatakan sebagai kondisi paling akut dari sebuah konflik. Konflik perang masih diketahui kapan awal dan akhirnya, akan tetapi konflik kontemporer tidak memiliki awalan dan tujuan yang jelas. Proses pergolakannya akan menyita waktu dan energi seluruh pihak yang terlibat dalam waktu yang relatif lama (tidak dapat diprediksi).

Ketidakmampuan memprediksi inilah yang kemudian disebut sebagai konflik yang kompleks. PBB mendefinisikan istilah 'complex emergency' sebagai keadaan darurat yang disebabkan oleh berbagai hal seperti konflik sara (suku, agama, dan ras), kelaparan, perpindahan orang, kedaulatan sengketa atau pemecahan pemerintah nasional dan keamanan publik. $^{9}$ Keadaan darurat 
dalam pengertian ini, menurut prediksi Goodhand dan Hulme, disebabkan oleh kekuasaan dan langkanya sumber daya. Vayrynen juga setuju dengan penyebab ini, dengan mengatakan:

\section{A humanitarian emergency can be defined as a profound social crisis in which a large number of people die and suffer from war, disease, hunger, and displacement owing to man-made and natural disasters, while some other may benefit from it. 10}

Walau Vayrynen menggunakan istilah humanitarian emergency, dalam tulisan ini tetap menggunakan istilah CPE. Jika menggunakan istilah humanitarian emergency maka penyebab konflik adalah manusia, padahal perubahan alam dan ekosistem juga mampu memunculkan konflik yang berkepanjangan antar manusia. ${ }^{11}$

Lengkapnya, menurut WHO dalam Consultation on Applied Health Research Priorities in Complex Emergencies, CPE mendeskripsikan situasi yang mempengaruhi kehidupan sebagian penduduk sipil dalam satu negara atau beberapa negara yang biasanya melibatkan faktor-faktor seperti konflik sipil, kekurangan pangan, perpindahan populasi, hingga masalah yang sangat kompleks yakni tingkat kematian yang signifikan. ${ }^{12}$ Pengertian di atas menunjukkan bahwa CPE bukan sebagai tools untuk menganalisa konflik tetapi lebih pada usaha untuk mendeskripsi keadaan sumber daya saat konflik terjadi.

Goodhand dan Hulme memaparkan beberapa istilah yang menyebabkan konflik menjadi complex political emergence, yakni sebagai berikut: 13

1. Political origins. Politik yang identik dengan kepentingan (interest) dan kekuasaan (power), menjadi pemicu utama konflik. Selain itu, keterbatasan sumber daya membuat berbagai pihak berlomba-lomba untuk memanfaatkannya. Dalam situasi ini, akan selalu ada pihak yang dirugikan. Pihak yang dirugikan inilah yang nantinya akan memulai konflik dan menggunakan berbagai cara untuk merebut kembali sumber daya. Saat konflik sedemikian rupa berkembang di lapangan, negara baru hadir. Alhasil, kebijakan yang belakangan dibuat untuk menengahi konflik, justru menjadi pemicu konflik baru.

2. Protracted duration. Konflik yang berkepanjangan akan memunculkan berbagai macam 
konflik baru (complex emecgence).

Walau pada awalnya perang menjadi pemicu dan genjatan senjata menjadi alat perdamaian sementara, ini bukan berarti konflik selesai justru awal munculnya konflik-konflik baru. Palestina dan Israil adalah contoh konflik kemanusian yang hingga sekarang belum selesai. Konflik yang berawal dari perebutan wilayah ini telah menyebabkan munculnya konflik lain seperti hak asasi manusia, kelaparan, kekurangan kebutuhan primer dan skunder, ketakutan, dan lain sebagainya.

3. Social cleavages. Perbedaan struktur sosial, ras, agama, budaya, ekonomi, dan identitas antara satu kelompok dengan kelompok lain menjadi akar CPE. konflik ini seringkali terjadi dalam satu negara yang masih memiliki sifat kedaerahan tinggi dan belum menghargai sistem multicultural. Konflik juga bisa terjadi antara satu komunal minoritas dengan negara karena masalah keamanan, pengakuan dan penerimaan, akses dan fasilitas yang adil untuk faslitas layanan. Konflik suku Dayak-
Madura di Kalimantan, sparatisme Gerakan Aceh Merdeka di Aceh, Operasi Papua Merdeka di Papua, adalah contoh social cleavages di Indonesia.

4. Predatory social formations. Adanya penanaman antipati terhadap kelompok lain dan loyalitas pada kelompok sendiri menjadi akar masalah CPE. CPE juga terjadi melalui jalur mobilisasi dan manipulasi penguasa yang oportunis kepada satu kelompok untuk 'memangsa' kelompok lain.

5. Contflict within and across state boundaries. CPE bukan hanya konflik yang terjadi dalam negara, antar negara, dan antar beberapa kelompok negara juga. Perang dunia I dan II, perang dingin, dan perang salib menunjukkan bahwa konflik telah terjadi pada level lintas batas negara.

Dari lima hal yang menyebabkan munculnya CPE, kita bisa sepakat bahwa masalah terbesarnya bermuara pada negara (state). Cliffe dan Luckham mengatakan bahwa keputusasaan kelompok (mayoritas-minoritas), penderitaan individu, dan perang bersenjata adalah bukti keruntuhan politik 
negara. ${ }^{14}$ Di bawah ini akan dibahas studi kasus konflik yang telah barlangsung lama yakni konflik Ahmadiyah di Indonesia. Konflik ini ibarat ikan di lautan, timbul-tenggelam. Sudah ada beberapa kebijakan yang dihasilkan tetapi konflik ahmadiyah tetap muncul dan tidak dapat diprediksi kapan berakhir.

\section{Kasus Ahmadiyah Di Indonesia}

Untuk lebih memahami CPE dalam konteks kebijakan publik, tulisan ini menggunakan studi kasus perseteruan ahmadiyah di Indonesia. Kasus ini menarik untuk dikaji karena sejak kedatanganya hingga sekarang bahkan tidak diketahui kapan berakhirnya. Ahmadiyah telah menuai berbagai respon di masyarakat baik dalam bentuk penerimaan ataupun penolakan. Hingga hari ini, ada beberapa kebijakan yang telah dikeluarkan seperti SKB 3 Mentri (Kemendagri, Kemenang, dan Jaksa Agung), dan fatwa haram MUI.

Walau sudah mendapat penolakan, jamaah ahmadiyah tetap eksis malah semakin berkembang. Konflik ini jika dipandang dari sudut aktor, maka yang berkepentingan atas dasar agama adalah: 1) jamaah ahmadiyah selaku pihak yang mendapat menolakan untuk menjalankan proses peribadatan; 2) masyarakat Islam sebagai pihak yang resah dan terancam 68 akan penyebaran paham ahmadiyah di lingkungan keluarga; 3) tokoh masyarakat menerima keluhan masyarakat; 4) MUI selaku organisasi yang memiliki otoritas untuk memutuskan perkara Islam; dan 5) pemerintah selaku pihak yang memegang otoritas penuh untuk memutuskan kebijakan apa yang harus diambil terkait konflik yang telah berkembang di masyarakat.

Cara mengurai benang kusut kasus ahmadiyah adalah dengan kembali melihat sejarah muncul di Indonesia, awal penolakan masyarakat, dan melihat argumen tiap aktor-aktor yang berkonflik. Jemaah Ahmadiyah merupakan gerakan keagamaan (Islam) yang didirikan di Qadian oleh H. Mirzam Gulam Ahmad tahun 1889. Sebagai gerakan keagamaan atau sebuah organisasi, nilai-nilai dan praktek keagamaan adalah Islam. ${ }^{15}$ (baca: www.ahmadiyya.or.id).

Ahmadiyah masuk ke Indonesia pada tahun 1925 dibawa oleh Rahmat Ali. Pada tahun 1932 Jemaah Ahmadiyah Indonesia (JAI) telah berdiri di Jakarta dan semenjak itulah perkembangannya sangat pesat, menyebar ke Jawa Barat dan berbagai daerah di pulau Jawa. Semenjak tahun 1935 pusatnya pun berada di Jakarta dan pada tahun 1987 pindah ke Parung di Bogor (www.alislam.org). Dalam perkembangan selanjutnya pada 


\section{Ihsan Rahmat \\ KEBIJAKASANAAN DAN CDMPLEX PDLITILAL EMERGENEE}

tahun 1953, organisasi ini telah mendapat pengesahan dari pemerintahan Republik Indonesia. Menteri Kehakiman R.I dengan SK. No. J. A/5/23/13 tanggal 13 Maret 1953 mengesahkan JAI (Jemaat Ahmadiyah Indonesia) sebagai Badan Hukum, surat keputusan tersebut dimuat dalam tambahan Berita Negara Republik Indonesia pada tanggal 31 Maret 1953 No. 26.16

Konflik masyarakat Islam di Indonesia dengan JAI berawal dari keputusan Mujamma' al-Fiqh al-Islami Organisasi Konferensi Islam(OKI) Nomor 4 (4/2) dalam Muktamar II di Jeddah, Arab Saudi, pada tanggal 10-16 Rabi' alTsani 1406 H / 22-28 Desember 1985 M tentang Aliran Qadiyaniyah, yang antara lain menyatakan bahwa aliran Ahmadiyah yang mempercayai Mirza Ghulam Ahmad sebagai nabi sesudah Nabi Muhammad dan menerima wahyu adalah murtad dan keluar dari Islam karena mengingkari ajaran Islam yang qath'i dan disepakati oleh seluruh ulama Islam bahwa Muhammad SAW. Karena Indonesia pada tahun 1985 masih dikuasai kediktatoran orde baru, maka terlihat tidak muncul konflik keagamaan (walaupun terjadi konflik, sifatnya masih konflik laten). Barulah sejak diputuskannya fatwa MUI No 11/MUNAS VII/MUI/15/ tahun 2005, penolakan besar-besaran terhadap JAI terjadi.

Keluarnya fatwa MUI tahun 2005 dan didukung oleh semangat reformasi yang menjunjung tinggi kebebasan menyampaikan pendapat, konflik yang awalnya laten berubah menjadi konflik terbuka (kontak fisik). Konflik ahmadiyah mencapai puncaknya pada tahun 2006 ditandai dengan penyerangan besarbesaran terhadap JAI di sejumlah tempat seperti Lombok Tengah, Jambi dan Jawa Barat. Fatwa-fatwa yang dikeluarkan MUI menjadi alasan legal untuk melenyapkan JAI.

Dari penjelasan di atas, dapat kita tafsirkan bahwa kekuasaan yang dimiliki MUI menggambarkan sebuah hegemoni kaum mayoritas terhadap minoritas. Kekuasaan dan kewenangan yang terlegitimasi mencoba melakukan penyeragaman terhadap aliran-aliran yang berbeda. Penyeragaman akan membentuk sebuah identitas dan mewujudkan sebuah kepatuhan kaumnya. Dengan kata lain akan terbentuk dua posisi dimana pihak yang dominan menguasai pihak yang minor (menguasai dan dikuasai). Sehingga terbentuk sebuah struktur beserta relasirelasinya dalam sebuah kehidupan beragama. Ketika agama dilembagakan (menjadi sebuah 
institusi) maka produksi dan reproduksi kekuasaan atas kepentingan akan terjadi.

Semakin berkembangnya dan bringasnya konflik di lapangan, tahun 2008 pemerintah mengeluarkan kebijakan untuk menyikapi masalah JAI. Kebijakan tertuang dalam Surat Keputusan Bersama (SKB) Menteri Agama Nomor: 3 Tahun 2008, Jaksa Agung Nomor: Kep033/A/Ja/6/2008, dan Menteri Dalam Negeri Republik Indonesia Nomor: 199 Tahun 2008. Pada dasarnya, SKB 3 menteri menetapkan 7 (tujuh) ketentuan tentang peringatan dan perintah kepada penganut, anggota, dan/atau anggota pengurus JAI dan warga masyarakat Ahmadiyah.

Intisari dari SKB tersebut di satu pihak mengakui dan melindungi eksistensi Jemaat Ahmadiyah di seluruh Indonesia, namun dilain pihak SKB tersebut mengatur agar dalam menjalankan aktivitasnya JAI tidak melakukan kegiatan diluar lingkungannya yang dapat mengganggu keamanan dan ketertiban. Pembatasan terhadap Jemaat Ahmadiyah hanya pada hal penyebaran paham atau ajaran yang menyimpang dari pokok-pokok ajaran agama Islam, yaitu pengakuan adanya nabi setelah Nabi Muhammad SAW, sebagaimana disebutkan dalam butir 2 SKB dimaksud, yaitu: “Memberi peringatan dan memerintahkan bagi seluruh penganut, pengurus Jemaat Ahmadiyah Indonesia (JAI) sepanjang menganut agama Islam agar menghentikan semua kegiatan yang tidak sesuai dengan penafsiran agama Islam pada umumnya. Seperti pengakuan adanya nabi setelah Nabi Muhammad SAW".

Berlakunya SKB 3 Menteri ini ditopang dengan UU Nomor 1/PnPs/1965 tentang Pencegahan Penyalahgunaan dan/atau Penodaan Agama jo. UU Nomor 5 Tahun 1969 tentang Pernyataan Berbagai Penetapan Presiden dan Peraturan Presiden sebagai Undang-Undang, yang bertujuan untuk menghindari konflik yang terjadi di dalam masyarakat terhadap pro dan kontra atas kehadiran JAI. Namun pada kenyataannya, SKB 3 Menteri ini tidak terealisasi dengan baik.

Akibatnya di sejumlah provinsi dan kota banyak bermunculan peraturan daerah (Perda) atau keputusan kepala daerah yang melarang keberadaan dari JAI untuk melakukan aktivitas keagamaan dan kegiatan sosial lainnya. Tindakan pemerintah daerah yang melarang keberadaan Jamaah Ahmadiyah di Indonesia terjadi karena terdapat kesalahan dalam memahami esensi SKB 3 Menteri yang banyak ditafsirkan sebagai 


\section{Ihsan Rahmat \\ KEBIJAKASANAAN DAN CDMPLEXPDLITILAL EMERGENCE}

pelarangan terhadap Jemaat Ahmadiyah di Indonesia.

Beberapa tahun terakhir ini, konflik Ahmadiyah terjadi di berbagai tempat, yakni: 1) Tahun 2013 silam terjadi usaha penggusuran warga JAI di Desa Srimenanti Kecamatan Sungailiat, Kabupaten Bangka Belitung yang ditengarai didukung oleh tokoh masyarakat, agama dan bupati. Walau sudah dimediasi oleh utusan Kemendagri, konflik ini masih terus berlangsung hingga hari ini; 2) Tanggal 6 Februari 2011, terjadi penyerangan JAI di Desa Cigelis Kec. Cikeusik Kabupaten Pandeglang, Banten. Serangan itu berujung pada 3 orang korban meninggal dan beberapa lainnya luka-luka dari pihak Ahmadiyah.

Dalam video yang dirilis oleh situs YouTube.com, digambarkan bahwa serangan yang dilakukan oleh massa terhadap JAI sangat brutal; dan 3) Tahun 2007 terjadi penggusuran JAI di tanah Lombok. Malangnya hingga hari ini warga JAI masih di pengungsian dan hakhak konstitusi mereka tidak dipenuhi negara. Banyak anak pengungsi lahir dan dibesarkan di pengungsian Asrama Transito yang tidak mendapat dukungan pemerintah sejak Januari 2007. Bahkan menurut kompas.com, anak-anak dari pengungsi JAI sering dihina dan dianiaya oleh anak-anak sebaya mereka hingga pemerintah mengungsikan 40 anak ke Jawa Barat.

\section{Agenda Pembenahan}

Upaya untuk memahami CPE melalui kebijakan publik dapat dilakukan dengan memberi perhatian pada dua aspek sekaligus, yakni substansi kebijakan dan proses kebijakan. Dari sisi substansi kebijakan, akar penyebab konflik yang umum terjadi disebabkan karena variasi pertentangan nilai dan kepentingan aktor kebijakan. Para ahli konflik menengarai bahwa konflik atas substansi kebijakan tersebut terutama dipicu oleh pendekatan konvensional dalam studi dan praktek kebijakan selama ini yang seringkali mengandalkan data dan informasi.

Pada saat pendekatan evidence-based policy pertama kali muncul dan diterapkan di Inggris, para ahli sangat yakin bahwa pendekatan tersebut akan efektif dalam megelola perbedaan nilai dan kepentingan. Hal itu disebabkan oleh kemampuan pendekatan ini untuk menghindarkan basis komunikasi, negosiasi, dan pertarungan antar aktor yang relatif jelas berupa data dan informasi, pendekatan kebijakan berbasis bukti juga dianggap mampu membantu merumuskan kebijakan yang tepat serta menyelesaikan masalah secara lebih efektif. 
Banyaknya variabel yang harus diperhitungkan dalam proses kebijakan seringkali menggeser peran bukti (data dan informasi) dalam proses kebijakan. Bahkan beberapa ahli beranggapan bahwa penggunaan bukti sebagai satu-satunya basis, atau basis utama, dalam proses kebijakan dengan menggeser variabelvariabel yang lain hanya akan menjadikan kebijakan publik sebagai arena konflik. Oleh karenanya, sejumlah ahli merekomendasikan untuk menggeser pendekatan evidence-based policy dan menggantinya dengan evidence-informed, value-based, atau right-based policy. ${ }^{17}$

Untuk memoderasi konflik yang dipicu oleh perbedaan dan pertentangan nilai, para ahli mengusulkan sejumlah metode. Sebagaimana dirangkum oleh de Graaf dkk, terdapat beberapa metode untuk mengelola konflik Ahmadiyah di Indonesia, antara lain:18

1. Firewalls, di mana nilai yang berbeda didistribusikan kepada lembaga atau orang yang berbeda untuk diperjuangkannya. Semua nilai mendapatkan wadah realisasinya. Kendatipun demikian, metode ini harus dikelola sedemikian agar koherensi dan sinergi kebijakan tetap bisa diwujudkan di tengah fragmentasi tanggung jawab.
2. Bias, di tengah konflik nilai, satu atau beberapa nilai tertentu dianggap tidak penting dan dikesampingkan dari arena kebijakan. Metode ini umumnya ditopang oleh basis argumentasi dan pengukuran yang jelas. Namun seringkali kesulitan dalam mengelola kekecewaan yang muncul akibat dieksklusinya nilai tertentu dan sarus siap mengelola oposisi.

3. Casuistry, di mana pemerintah membuat keputusan tertentu untuk mengelola konflik nilai berdasarkan spesifikasi (mencari kasus-kasus yang mirip). Metode ini sangat mengandalkan daya analogi dan komparasi para pembuat kebijakan.

4. Cycling, di mana nilai tertentu dianggap penting dan relevan hanya utuk jangka waktu tertentu hingga akhirnya muncul penolakan dan digantikan oleh nilai-nilai yang lain.

5. Hybridization, ditandai oleh kombinasi berbagai nilai yang saling bertabrakan sebagai akibat dari ditambahnya nilai baru pada kebijakan sebelumnya yang hanya mewadahi nilai tertentu. 
6. Inkrementalism, di mana secara perlahan nilai tertentu mendapatkan prioritas atau tekanan dalam kebijakan publik dibandingkan dengan nilai-nilai lain yang tadinya diberi perhatian sama.

Strategi-strategi di atas memberikan ruang bagi kebijakan publik menentukan pilihan mana yang terbaik dalam menyelesaikan konflik, tetapi tidak menjamin keberhasilan CPE. Ada beberapa variabel lain yang harus diperhatikan seperti partisipasi publik atau bahkan kolaborasi yang memanfaatkan aktor lain (di luar aktor konflik) untuk menyelesaikan konflik.

\section{E. Kesimpulan}

Konflik Ahmadiyah di Indonesia sudah memasuki fase kritis. Dalam paradigma $\mathrm{CPE}$, konflik ini mengandung unsur-unsur seperti political origin, protracted duration, social cleavages, bahkan berujung pada predatory social formations. Predatory social formations adalah ciri yang paling kentara dalam konflik Ahmadiyah. Terbukti dengan beragam kasus yang tersebar di sebagian pulau Jawa bahwa setiap melihat komunitas Ahmadiyah, kebanyakan umat Islam langsung mengklaimpaham sesat. Bahkan tidak jarang di beberapa lokasi timbul kontak fisik yang berujung pada pembakaran bangunan dan kematian di pihak Ahmadiyah.

Sebelum konflik ini menjadi sedemikian kompleks, negara dengan otoritasnya telah menenggarai dengan beberapa kebijakan. Tetapi kebijakan yang dihasilkan belum mampu menghilangkan konflik. Kembali ke argumen dalam tulisan ini bahwa seberapapun hebatnya kebijakan, selama aktor-aktor masih mempertahankan prinsip nilai, klaim, dan kepentingan, selama itu juga kebijakan menjadi sebuah keniscayaan dalam konflik. Perlunya antar aktor menarik diri atau setidaknya mengurangi eksistensi dalam konflik dengan tujuan akhir mencari perdamaian bersama. 


\section{Referensi}

${ }^{1}$ William M. Dunn, Pengantar Analisis Kebijakan
Publik, (Yogyakarta: UGM Press, 1999). hlm. 13.
${ }^{2}$ Gabriel Lele, Pengelolaan Konflik dalam
Kebijakan Publik, dalam Kebijakan Publik dan
Pemerintahan Kolaboratif: Isu-Isu Kontemporer, Ed.
Agustinus Subarsono, (Yogyakarta: Gava Media, 2016).
hlm. 2.
${ }^{3}$ dalam Jenny Stewart, Value Conflict and Policy Change, Review of Policy Research, Vol. 23, No. 1, 2006. hlm. 17.

${ }^{4}$ Dean G. Pruitt dan Jeffrey Rubin. Social Conflict: Escalation, Stalemate, and Settlement. (New York: McGraw-Hill Inc, 1986). Hlm. 9-19.

${ }^{5}$ Weerahandi, H., Poeran, J., Nassisi, D., \& Mazumdar, M. When Practice and Policy Conflict : Blood Cultures in Community-acquired Pneumonia. American Journal of Emergency Medicine, Vol. 33, No. 1, 2015.hlm. 1246-1248.

${ }^{6}$ Lionel Cliffe dan Robin Luckham. Complex Political Emergencies and The State: Failure and The Fate of The State, Third World Quarterly, Vol. 20, No. 1, 1999. hlm. 27-50.

${ }^{7}$ Ciarán O'Kellydan Melvin J. Dubnick, . Taking Tough Choices Seriously: Public Administration and Individual Moral Agency. Journal of Public AdministrationResearchand Theory, Vol. 16, No. 1, 2005. hlm. 393-415. juga lihat Michael W. Spicer, Value Conflict and Legal Reasoning in Public Administration. Administrative Theory \& Praxis, 314, 2009. hlm. 537555.

${ }^{8}$ Jonathan Goodhand dan David Hulme, From Wars to Complex Political Emergencies: Understanding Conflict and Peace-building in The New World Disorder. Third World Quarterly, Vol. 20, No. 1, 1999. hlm. 13-26.

${ }^{9}$ Harriss, J. Introduction: A Time of TroublesProblems of International Humanitarian Assistance in The 1990s, in J. Harriss (ed.): The Politics of Humanitarian Intervention, Save the Children and Pinter, London,1995.hlm. 1-16.

${ }^{10}$ Raimo Vayrynen, The Age of Humanitarian Emergencies, Research for action 25, UNU World Institute for Development Economics Research, 1996, Helsinki. hlm. 19.

${ }^{11}$ Hughes, S. P. M. Case Study of Three International Relief Agencies: Ethics, Humanitarian Aid and Complex Political Emergencies. Dissertation, 2004. University of California at Berkeley. hlm. 87.

${ }^{12}$ Hughes, S. P. M. Case Study of Three International Relief Agencies.... hlm. 98.

${ }^{13}$ Jonathan Goodhand dan David Hulme, From Wars to Complex Political Emergencies... hlm. 13.26.

${ }^{14}$ Lionel Cliffe dan Robin Luckham. Complex Political Emergencies and The State... hlm. 32.

\author{
${ }^{15}$ Sejarah Singkat Ahmadiyah. Diakses \\ http://ahmadiyah.id/ahmadiyah \\ ${ }^{16}$ Munasir Sidik,Dasar-Dasar Hukum dan \\ Legalitas Jemaat Ahmadiyah Indonesia. (Jakarta: Jemaat \\ Ahmadiyah, 2008).hlm. 21.
}

${ }^{17}$ Mario, E. G., Norton,. Andrew, G., \& Sophia, V, Building Equality and Opportunity through Social Guarantees: New Approaches to Public Policy and The Realization of Rights. (Washington: World Bank, 2009).

${ }^{18}$ De Graaf, Gjalt., Huberts, Leo, dan Smulders, Remco, Coping with Public Value Conflicts, Journal of Administration \& Society, 2014.hlm. 1-27. 